\title{
Erratum to: Entre el Aquí y el Allá: International Schooling and the Colonized Mind
}

\author{
Alexandra Arráiz Matute
}

\section{Erratum to:}

Chapter 13 in: G.J. Sefa Dei and M. McDermott (eds.), Politics of Anti-Racism Education: In Search of Strategies for Transformative Learning, Explorations of Educational Purpose 27, https://doi.org/10.1007/978-94-007-7627-2_13

The first name of author Alexandra Arráiz Matute was incorrectly tagged in the xml of the previously published version as Alexandra Arráiz. This has now been corrected, and the first name is Alexandra.

\footnotetext{
The updated online version of this chapter can be found at https:// doi.org/10.1007/978-94-007-7627-2_13
} 